\title{
Analyses of variability, euclidean clustering and principal components for genetic diversity of eight Tossa Jute (Corchorus olitorius L.) genotypes
}

\author{
Md. Mia Mukul ${ }^{*}$, Nargis Akter ${ }^{2}$, Md. Golam Mostofa ${ }^{3}$, Md. Sohanur Rahman ${ }^{4}$, Md. Al-Emran Hossain ${ }^{5}$, \\ Dinesh Chandra Roy ${ }^{6}$, Sadia Afrin Jui ${ }^{7}$, Md. Meftahul Karim ${ }^{8}$, Jannatul Ferdush ${ }^{9}$, Md. Mozammel \\ Hoque $^{10} \&$ Md. Abul Fazal Mollah ${ }^{11}$ \\ 1,2,3,7Breeding Division, Bangladesh Jute Research Institute (BJRI), Ministry of Agriculture, Manik Mia Avenue, Dhaka-1207, Bangladesh \\ ${ }^{4}$ Pest Management Division; ${ }^{9}$ Fibre Quality Improvement Division, BJRI, Manik Mia Avenue, Dhaka-1207, Bangladesh \\ ${ }^{5}$ Agronomy \& Farming System Division, Bangladesh Sugar Crop Research Institute (BSRI), Ishurdi-6620, Bangladesh \\ ${ }^{6}$ Breeding Division, Bangladesh Institute of Nuclear Agriculture (BINA), BAU Campus, Mymensingh-2202, Bangladesh \\ ${ }^{8}$ Jute Agricultural Experiment Station, BJRI, Manikganj, Bangladesh \\ ${ }^{10,11}$ Jute Research Regional Station, BJRI, Rangpur, Bangladesh \\ *Email: mukulbjribreeding@gmail.com or mukul@bjri.gov.bd
}

\section{ARTICLE HISTORY}

Received: 29 June 2020

Accepted: 16 September 2020

Published: 01 October 2020

\section{KEYWORDS}

Genetic diversity; cluster analysis; principal component analysis; genotypic and phenotypic coefficient of variation; heritability; genetic advance

Abbreviations

BJRI-Bangladesh Jute Research Institute; BARJ-Basic and Applied Research on Jute; RCBDRandomised Complete Block Design

\section{ABSTRACT}

An investigation was done to assess the genetic variability, character associations, and genetic diversity of eight jute genotypes for seven morphological traits in a randomised complete block design at Bangladesh Jute Research Institute during 15 March, 2018 to 31 December, 2019. Analyses results revealed significant differences $(\mathrm{P}<0.01)$ among all genotypes for studied traits indicating the presence of variability. All the lines performed better than one control (JRO-524), and the line (0-0412-9-4) provided good results for desired traits than all controls. Jute fibre yield showed the highest broad sense heritability (98.54\%). The studied jute morphological traits i.e. Plant population, the plant height, green weight, dry fibre yield and dry stick yield gave high heritability along with high genotypic and phenotypic variances, genetic advances in percent of the mean, highly significant and positive correlations. It indicates the possibility of crop improvement through phenotypic selection and maximum genetic gain, simultaneously at the genotypic-phenotypic level. Clustering analysis grouped all genotypes into three distinct clusters. The cluster II showed the highest mean values for all traits followed by cluster I and III. The first two principal components with higher Eigen values $(>1.0)$ accounted for $90.88 \%$ of the total variation in the principal component analysis. PCA and cluster analyses indicated that the advanced breeding line 0-0412-9-4 made its individual cluster II with higher inter-cluster distance and higher fibre yield $\left(3.12 \mathrm{t} \mathrm{ha}^{-1}\right)$. The investigation was done to select the genotype(s) with good fibre yield and distinct features in respect of developing high yielding Tossa jute variety for cultivation in the farmers' field. This genotype 0-0412-9-4 was selected based on higher plant height, base diameter, fibre yield content. It will be developed as a high yielding variety considering its' higher genetic variability, heritability, genetic advance, significant associations for desirable characters.

\section{Introduction}

Jute is a natural fibre producing diploid $(2 n=2 x=14)$ crop belonging the genus Corchorus, Family Tiliaceae. Among more than 100 species of this genus, only two species namely white jute (Corchorus capsularis L.) and Tossa jute (Corchorus olitorius L.) are commercially cultivated (1). Both the cultivated species are distinguished by morphological and physiological characters. Tossa jute or dark jute or Bogi jute species are more susceptible to various biotic and abiotic stresses than white jute or deshi jute

(c) Mukul et al (2020). This is an open-access article distributed under the terms of the Creative Commons Attribution License, which permits unrestricted use, distribution and reproduction in any medium, provided the original author and source are credited (https://creativecommons.org/licenses/by/4.0/).

To cite this article: Mukul M M, Akter N, Mostofa M G, Rahman M S, Hossain M A, Roy D C, Jui S A, Karim M M, Ferdush J, Hoque M M, Mollah M A F. Analyses of variability, euclidean clustering and principal components for genetic diversity of eight Tossa Jute (Corchorus olitorius L.) genotypes. Plant Science Today. 2020;7(4):564-576. https://doi.org/10.14719/pst.2020.7.4.854 
species in Bangladesh (2). However, they are characterised by narrow genetic variability for adaptability to various agro-ecological zones; fibre yield; quality; and susceptibility to diseases and pests. Jute is a self-pollinated crop with 5\% possible outcross, and the plant breeders face difficulties to develop new varieties through conventional breeding systems. Jute is the second most important natural fibre crop after cotton (Gossypium spp.) in Indian sub-continent (3). It has a great potentials for manufacturing diversified value-added industrial products and packaging materials from its fibre content. So, the jute breeders should be aware of maintaining genetic diversity among varieties, lines, and improving the genetic resources through the conservation of breeding materials.

These genetic materials exist with high genetic variability and adaptability to various environments where they have been originated and domesticated (3). It was opined in earlier studies $(1,4)$ that there is a limitations in crossing between these two cultivated jute species ( $C$. capsularis and $C$. olitorius) due to strong sexual incompatibility. Therefore, the valuable genetic variability from diverse germplasms both at intra- and inter-specific levels should be explored and utilised for breeding purposes $(3,4)$. Diversity means the degree of differentiation between or within species (5). The evolution of crop plants naturally or artificially depends on the existing diversity among the plant population (6). The highest similarities among the plant species indicate the lower possibility of improvement in plant performances for desired traits; while the highest heterozygosity play an essential role to identify the true hybrids/breeding materials or the best parent(s) in the breeding programme of varietal improvement leading to greater opportunity for crop improvement to the plant breeders (7).

Genotypic diversity and variability were considered as prerequisites for developing new high yielding, climate-smart and agro-ecologically adapted variety $(8,9)$. The proper knowledge of evolutionary relationships among the germplasms has utmost importance to the breeders for crop improvement in various systematic fashions to incorporate the useful variations in their genetic architecture $(10,11)$. The breeders should have sound knowledge on the variability of different morphological characters such as the height of the plant, diameter of the stem, fresh weight of the green plant with and without leaves, dry fibre weight and dry stick weight for yield improvement (12). These traits reflect on the genetic composition of the cultivar and on the interaction between genotype and its environment where it is expressed (13, 14). Moreover, high genetic advance associated with high heritability estimate offers the most effective selection opportunity for a particular trait (15).

The relationships among the yield and yield attributing traits in jute plants should be emphasised by the breeders for making them properly parental selection for fibre yield improvement techniques (16). The assessment of relationships among the fibre yield and yield attributing characters helps to identify the contribution of traits towards fibre yield
(17). The plant breeders often measure various characters in jute crops; and all the variables may not be the selection criteria for evaluation, characterisation and management of jute germplasm (18). In this regard, the principal component analysis would be used to explore the breeding patterns and eliminate the redundancy from large data sets as morphological and physiological variations routinely occur in crop species (19). Earlier studies (20, 21) observed that, principal components analysis for the studied characters of the experimental genotypes is important to determine the trends in multidimensional data sets. The PCA reduces relatively a large series of data into a smaller number of components by looking for groups that have very strong inter-correlation in a set of variables and each component explains per cent (\%) variation to the total variability. Since PCA extract all the key components and highlight their contribution towards the total variability, it can be the choice as a valuable tool to speed up the breeding programme $(22,23)$.

In this experiment, eight Tossa Jute genotypes including two pre-released varieties were investigated to select the genotype(s) having high variability, heritability, possibility of genetic advance for the desirable morphological characters etc. in order to utilize in varietal improvement programme through effective breeding systems.

\section{Materials and Methods}

\section{The geographical location of the experimental site}

The investigation was conducted in the experimental field of jute research regional station, Bangladesh Jute Research Institute (BJRI), Rangpur (2544'33.7"N89¹6'21.8"E) and Breeding Division of Bangladesh Jute Research Institute, Manik Mia Avenue, Dhaka (2345'26"N, 90²2'47"E), Bangladesh during $15^{\text {th }}$ March-December, 2018 for the first season and $15^{\text {th }}$ March-December, 2019 for the second season. The data were taken carefully in both seasons and then averaged for statistical analyses. The soil of the experimental site was sandy loam having $0.12 \%$ Nitrogen, $1.65 \%$ organic matter (OM), $30.0 \mathrm{ppm}$ available phosphorus, 0.25 meq \% exchangeable potassium, 34.62 ppm Sulphur, 2.32 ppm Zinc, 0.70 ppm Boron and $6.5 \mathrm{pH}$, average temperature maximum $32.3{ }^{\circ} \mathrm{C}$, minimum $11.2{ }^{\circ} \mathrm{C}$; annual rainfall $219.45 \mathrm{~mm}(24)$.

\section{Plant materials}

Eight Tossa jute genotypes, including six breeding lines and two control varieties (pre-released) were used in the experiment. List of these plant genotypes with their identifying morphological traits; type of plant; source of seed materials collection; country of origin are described in Table 1.

\section{Design of the experiment}

The investigation was performed in a RCBD with three replications $(25,26)$. For each genotype, one observational plot was maintained as a substitute for the missing plot and seed production purpose through the top cutting method. The plot size was 10 
Table 1. List of experimental Tossa jute genotypes, identifying characters, plant type, source of collection and origin.

\begin{tabular}{|c|c|c|c|c|c|}
\hline SL. No. & Genotype & Identifying morphological characters & Type of plant & $\begin{array}{l}\text { Source of } \\
\text { collection }\end{array}$ & $\begin{array}{l}\text { Country of } \\
\text { origin }\end{array}$ \\
\hline 1 & $\mathrm{G}_{1}=0-0512-6-2$ & Full green plant, lanceolate leaf & \multirow{6}{*}{$\begin{array}{c}\text { Advanced } \\
\text { breeding lines }\end{array}$} & \multirow{6}{*}{$\begin{array}{l}\text { Breeding } \\
\text { Division, BJRI }\end{array}$} & \multirow{7}{*}{ 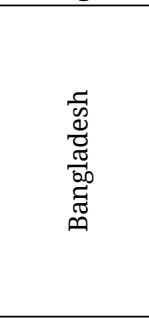 } \\
\hline 2 & $\mathrm{G}_{2}=0-0412-9-4$ & Stem \& leaf stipule red, ovate-lanceolate leaf & & & \\
\hline 3 & $\mathrm{G}_{3}=0-0411-10-4$ & Stem \& leaf stipule red, ovate-lanceolate leaf & & & \\
\hline 4 & $\mathrm{G}_{4}=0-049-1-3$ & Stem \& leaf stipule red, lanceolate leaf & & & \\
\hline 5 & $\mathrm{G}_{5}=0-0419-3-1$ & Stem, leaf stipule \& petiole red, ovate leaf & & & \\
\hline 6 & $\mathrm{G}_{6}=0-043-7-9$ & Stem \& leaf stipule red, narrow lanceolate leaf & & & \\
\hline 7 & $\mathrm{G}_{7}=\mathrm{BJRI}$ Tossa pat -8 (Robi-1) & $\begin{array}{l}\text { Stem, leaf stipule \& petiole reddish, lanceolate } \\
\text { leaf with a glossy surface }\end{array}$ & \multirow{2}{*}{$\begin{array}{c}\text { Released } \\
\text { variety } \\
\text { (Controls) }\end{array}$} & \multirow{2}{*}{$\begin{array}{l}\text { Gene Bank, } \\
\text { BJRI }\end{array}$} & \\
\hline 8 & $\mathrm{G}_{8}=\mathrm{JRO}-524$ (Exotic) & Full green plant, lanceolate leaf & & & India \\
\hline
\end{tabular}

$\mathrm{m}^{2}(4 \mathrm{~m} \times 2.5 \mathrm{~m})$, the plot-to-plot distance was $1 \mathrm{~m}$; line-to-line $30 \mathrm{~cm}$. Seeds of each jute genotype were sown on 15 March, 2018 in 13 rows $2.5 \mathrm{~m}$ long, plantto-plant 3-5 cm and line-to-line $30 \mathrm{~cm}$ distances.

\section{Growing of plants and intercultural operations}

For sandy loamy soil with well drainage system, chemical fertilisers: Urea, TSP, MoP and Gypsum (195, 50, 30, and $110 \mathrm{Kg} \mathrm{ha}^{-1}$, respectively) were used as basal dose during final land preparation (27). Urea was applied in 3 split times; $1 / 3^{\text {rd }}$ applied at land preparation for seed sowing, 30-40 and 60-75 days after sowing (DAS). Cow dung was used to reduce the use of urea. Plants were grown (Fig. 1) and agronomical practices viz. weeding, thinning, pesticidal spray and so forth were done as and when necessitated for proper plant growth and development in each experimental plot.

\section{Data collection}

Plants were harvested at 100 DAS depending on the maturity of plants. Data on plant population ( $\left.\mathrm{Lac} \mathrm{ha}^{-1}\right)$, the height of plant $(\mathrm{m})$, the girth of a plant (mm), the weight of plants with green leaves $\left(\mathrm{t} \mathrm{ha}^{-1}\right)$ and weight of plants without green leaves ( $\left.\mathrm{tha}^{-1}\right)$, dry jute fibre $\left(\mathrm{t} \mathrm{ha} \mathrm{h}^{-1}\right)$ and stick yield $\left(\mathrm{t} \mathrm{ha}^{-1}\right)$ of the jute plant were recorded carefully (28). Total number plants per $10 \mathrm{~m}^{2}$ plot was taken and converted into Lac ha- ${ }^{-1}$. Average plant height (m), plant base diameter (mm) were recorded from randomly selected 20 plants after harvesting from each replicated plot. Fibre yield $\left(\mathrm{kg} \mathrm{m}^{-2}\right)$ was taken from the inside plants of each plot avoiding border effects and converted to tha-1 (Table 2).

\section{Statistical Analyses}

Analysis of variance (ANOVA) and least significant differences (LSD) were computed for all traits using statistical analysis software STATISTIX10 (29) for estimation of significant differences among all genotypes. Variance and covariance components, genetic parameters and relationships among all the traits were estimated using different equations (i-xiii) in Microsoft Excel (MS Office 2016).

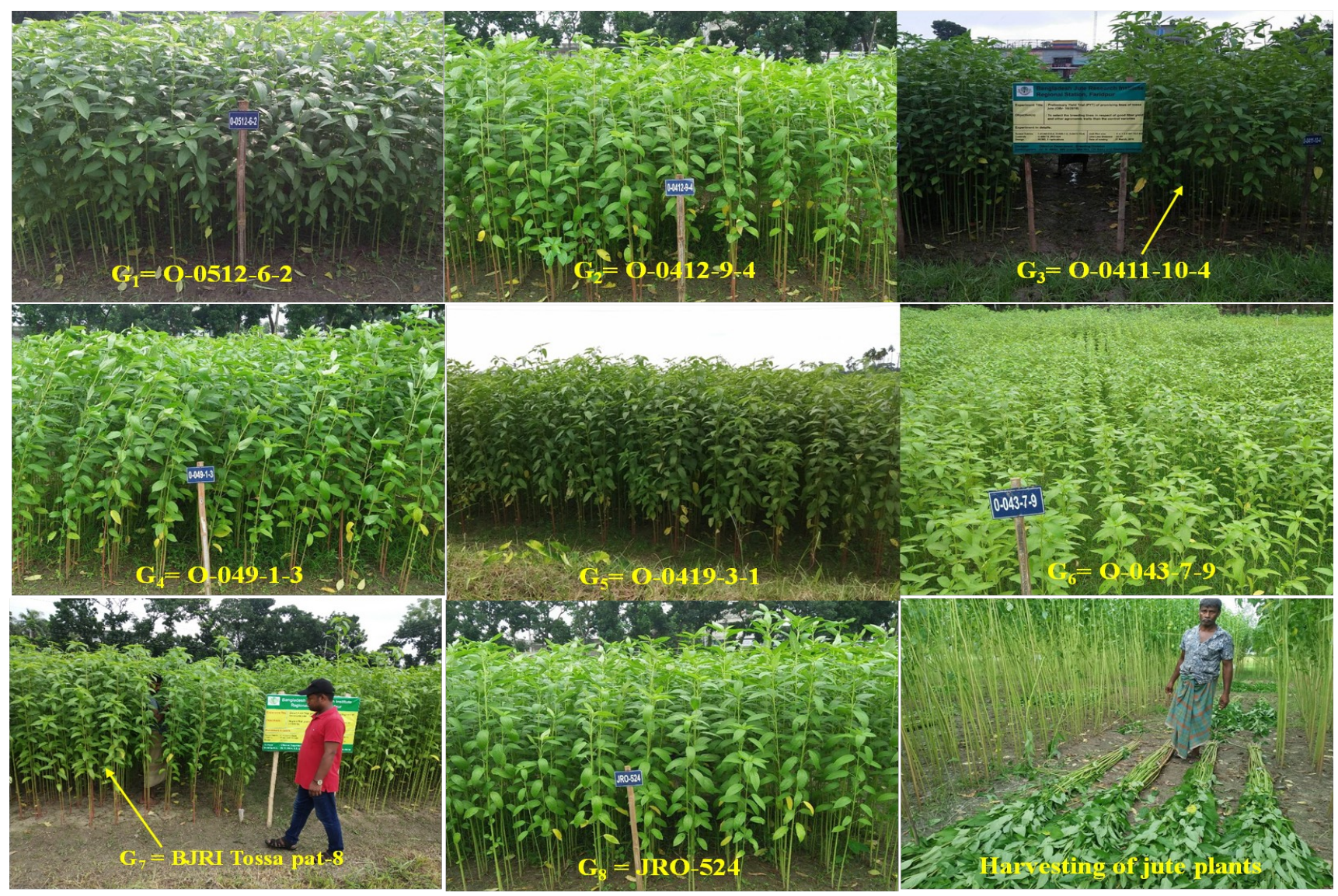

Fig. 1. Growing and harvesting of jute genotype $\left(G_{1} \ldots . G_{8}\right)$ in the experimental field at BJRI, Rangpur, Bangladesh. 
Table 2. Morphological traits and their methods of measurement.

\begin{tabular}{cll}
\hline Sl.No. & \multicolumn{1}{c}{ Characters } & \multicolumn{1}{c}{ Method of collection from each replicate of treatment } \\
\hline 1 & PP-Plant population $\left(\right.$ Lac ha $\left.{ }^{-1}\right)$ & Total number of plants per plot \\
\hline 2 & PH-Height of the plants $(\mathrm{m})$ & The average height of 20 plants randomly selected \\
\hline 3 & BD-Base diameter or girth of the plant $(\mathrm{mm})$ & The average base diameter of 20 plants randomly selected \\
\hline 4 & GWL- Green weight with leaves $\left(\mathrm{t} \mathrm{ha}^{-1}\right)$ & Weight of total plants with green leaves after harvest \\
\hline 5 & GWL1- Green weight without leaves $\left(\mathrm{t} \mathrm{ha}^{-1}\right)$ & Weight of total plants without leaves after harvest \\
\hline 6 & FY-Dry fibre yield $\left(\mathrm{t} \mathrm{ha}^{-1}\right)$ & Total weight of dry fibre produced \\
\hline 7 & STY-Dry stick yield $\left(\mathrm{t} \mathrm{ha}^{-1}\right)$ & Total weight of dry stick produced \\
\hline
\end{tabular}

\section{Statistical parameters}

Mean, range, LSD, standard error (SE), standard deviation ( $\sigma \mathrm{x})$ and coefficient of variation (CV) for each variable was estimated. The genotype mean square $\left(\mathrm{MS}_{\mathrm{G}}\right)$ and error mean square $\left(\mathrm{MS}_{\mathrm{E}}\right)$ was estimated using the formula described by earlier researcher (30). The $\mathrm{MS}_{\mathrm{E}}$ was considered as error variance $\left(\sigma_{E}^{2}\right)$. LSD tests were checked from calculated and tabulated value of ' $\mathrm{F}$ ' at both $\mathrm{P}>0.05$ and $\mathrm{P}>0.01$ level. Pearson correlation coefficient among all characters in all possible combinations was estimated using the equation (ix, $\mathrm{x}$ ) (31).

\section{Variance and Co-variance matrices}

Genetic parameters like genotypic and phenotypic variance of the trait(s) were calculated using the equations (i and ii); and the genotypic, phenotypic and environmental covariance components between two traits were calculated using the equations (iii, iv and v) (32), which are provided below.

$$
\begin{aligned}
& G V \vee \sigma_{G}^{2}=\frac{M S_{G}-M S_{E}}{r} \ldots \ldots \ldots \ldots \ldots \ldots \ldots \text { (i) } \\
& \mathrm{PV} \text { or } \sigma_{P}^{2}=\sigma_{G}^{2}+\sigma_{E}^{2} \\
& \operatorname{GCV}(\%)=\frac{\sqrt{\sigma_{G}^{2}}}{\bar{X}} \times 100 \\
& \operatorname{PCV}(\%)=\frac{\sqrt{\sigma_{P}^{2}}}{\bar{X}} \times 100 \text {. } \\
& \operatorname{ECV}(\%)=\frac{\sqrt{\sigma_{E}^{2}}}{\bar{X}} \times 100
\end{aligned}
$$

Here, GV = Genotypic variance; PV = Phenotypic variance; $\mathrm{GCV}$ = Genotypic coefficient of variation; $\mathrm{PCV}=$ Phenotypic coefficient of variation; ECV = Environmental coefficient of variation;

$M S_{G}=$ Genotypic mean square value; $M S_{E}=$ Error mean square value; $\mathrm{r}=$ Number of replication; $\sigma_{E}^{2}=$ Environmental variance (Error mean square from the analysis of variance); $\bar{X} \vee \bar{Y}=$ Mean value of the trait/variable $\mathrm{X}$ or $\mathrm{Y}$ being evaluated.

\section{Heritability}

According to the equation (vi) suggested by earlier researchers (30, 33-35), the heritability for all studied morphological characters were estimated in the broad sense.

$$
h_{b s}^{2}(\%)=\frac{\sqrt{\sigma_{G}^{2}}}{\sqrt{\sigma_{P}^{2}}} \times 100 .
$$

Here, $h_{b s}^{2}=$ Heritability $\in$ the broad sense

\section{Genetic advance}

Genetic advance for all studied morphological characters of jute plants were assessed using the equation (vii) $(30,33)$. The equation (vii) suggested by an earlier researcher (36) was used for the estimation of genetic advance in percent of the mean for these traits. The results derived using these formulae in different investigations were published and described by an earlier researcher (37).

$$
\begin{aligned}
& G A=\frac{\sqrt{\sigma_{G}^{2}}}{\sqrt{\sigma_{P}^{2}}} \times K \times \sigma_{P} \ldots . . \\
& \operatorname{GAM}(\%)=\frac{G A}{\bar{X}} \times 100 .
\end{aligned}
$$

Where: $G A=$ Genetic advance; GAM (\%) = Genetic advance in the percentage of mean; $\mathrm{K}=$ the selection differential (2.06) at $5 \%$ selection intensity; $\sigma_{\mathrm{P}}=$ the phenotypic standard deviation (STDEV.S) of the character studied; $\bar{x}$ = grand mean of the character.

\section{Genotypic and phenotypic correlation co-efficient $\left(r_{G_{X Y}}, r_{P_{X Y}}\right)$}

The covariance components among the traits were computed using the equation (ix). The $r_{G_{X Y}}$ and $r_{P_{X Y}}$ for all possible combinations were estimated using these co-variance components and the equations (ixxii) $(30,34,38)$.

$$
\begin{aligned}
& \left.\operatorname{Cov}_{X Y}=\sum_{i=1,2, \ldots n}^{N}\left[\left(X_{i}-\bar{X}\right) \cdot\left(Y_{i}-\bar{Y}\right)\right] / N-1 \ldots \text { (ix }\right) \\
& r_{X Y}=\frac{\operatorname{Cov}_{X Y}}{\sqrt{\sigma_{X}^{2} \times \sigma_{Y}^{2}}} \\
& r_{G_{X Y}}=\frac{\operatorname{Cov}_{G} X Y}{\sqrt{\sigma_{G}^{2} X \times \sigma_{G}^{2} Y}} \\
& r_{P_{X Y}}=\frac{\operatorname{Cov}_{P} X Y}{\sqrt{\sigma_{P}^{2} X \times \sigma_{P}^{2} Y}}
\end{aligned}
$$

Where,

$\operatorname{Cov}_{X Y}=$ Covariance between variable $X \wedge Y$; 
$r_{X Y}=$ Correlation between variable $X \wedge Y$;

$r_{G_{X Y}}=$ Genotypic correlation between variable $X \wedge Y$;

$r_{P_{X Y}}=$ Phenotypic correlation between variable $X \wedge Y$;

$\mathrm{N}=$ Number of observation in the variable $\mathrm{X}$ or $\mathrm{Y}$

\section{Principle Component Analysis (PCA) and Euclidean Clustering}

PCA is an effective way to interpret the large experimental datasets by reducing the dimensionalities of huge datasets, increasing interpretability as well as minimising the information loss through the exploration of uncorrelated variables which successively maximise the variance components of the studied variables (39). It also reduces eigenvalues/eigenvectors problem. For this reason, PCA and adaptive data analysis techniques are important for searching the new variables having maximum variances (40). The Euclidean squared distances $\left(\mathrm{D}^{2}\right)$ grouped the genotypes based on genetic diversity according to Ward's method $(41,42)$. The Euclidean clustering and PCA were analysed using XLSTAT (Version 2020.4) statistical software (43). The cluster mean values, distance values, Dendrogram were assessed in cluster analyses; and Eigenvalues, variability, cumulative variability, vector components, scree plot, bi-plot, score plot were estimated in PCA.

\section{Results}

\section{Analysis of variances}

Analyses of variances (ANOVA) recorded that selected Tossa jute genotypes were highly significant $(* *, P \leq 0.01)$ due to mean square values regarding plant population, plant height, green weight without leaves, dry fibre yield and dry stick yield; and significant $(*, P \leq 0.05)$ for green weight with leaves; and non-significant for base diameter (Table 3).

\section{Mean performance of the genotypes}

Average performances for the studied morphological traits of all jute genotypes were estimated (Table 4). The highest plant $(3 \mathrm{~m})$ was observed in $\mathrm{G}_{7}$ followed by $G_{6}, G_{4}, G_{2}, G_{1}$; while the shortest plant was found in $\mathrm{G}_{5}(2.85 \mathrm{~m})$ followed by $\mathrm{G}_{3}, \mathrm{G}_{8}$. The genotype $\mathrm{G}_{2}$ showed higher green weight (48.98 $\left.\mathrm{tha}^{-1}\right)$ with leaves followed by $\mathrm{G}_{1}$; while $\mathrm{G}_{8}$ showed the lowest weight (40.44 $\mathrm{t} \mathrm{ha}^{-1}$ ) for green weight with leaves. The highest green weight without leaves $\left(38.52 \mathrm{t} \mathrm{ha}^{-1}\right)$ was recorded in $G_{2}$ followed by $G_{7}$; while the $G_{1}$, $G_{5}$ gave medium values; and the lowest was found in $G_{4}$
(31.10 t ha-1) followed by $\mathrm{G}_{6}, \mathrm{G}_{8}, \mathrm{G}_{3}$. The highest fibre yield (3.12 $\mathrm{t} \mathrm{ha}^{-1}$ ) was recorded in $\mathrm{G}_{2}$ nearest to $\mathrm{G}_{7}$ $\left(3.05 \mathrm{t} \mathrm{ha}^{-1}\right)$ where $\mathrm{G}_{1}$ gave medium, and lowest (2.68 t ha $^{-1}$ ) were found in $G_{8}$ followed by $G_{4}, G_{3}, G 6, G_{5}$. The genotype $G_{2}$ provided higher dry stick yield (10.31 t $\mathrm{ha}^{-1}$ ) compared to others; while the genotype $G_{3}, G_{5}$ recorded medium; and the $\mathrm{G}_{6}$ followed by $\mathrm{G}_{8}, \mathrm{G}_{4}, \mathrm{G}_{1}$, $\mathrm{G}_{7}$ recorded the lowest dry stick yield. It was observed that the $G_{2}$ gave the highest results for all phenological traits except plant height and stem base diameter compared to controls; while the $\mathrm{G}_{7}$ showed higher plant height and almost same fibre yield as the $\mathrm{G}_{2}$.

\section{Variability and genetic parameters}

The variability and genetic parameters like genotypic and phenotypic variance components (GV, PV), genotypic (GCV), phenotypic (PCV) and environmental (ECV) coefficient of variation, broadsense heritability $\left(h_{b}^{2} \dot{b}\right.$, Genetic advance (GA), Genetic advance (\%) of the mean (GAM) were estimated for seven morphological characters (Table 5). The highest GV, PV components (\%), GA and grand mean were $(6.270,8.263 ; 5.158,44.781)$ recorded for green weight with leaves of the plants. The GCVs were higher than the respective PCVs for all characters. The dry stick yield of the plant showed the highest GCV (9.351\%), PCV (10.086\%), ECV (6.543\%) and GAM (19.265\%). The lowest GV (0.003), PV (0.004), ECV (1.527\%) and GA (0.113) were recorded for plant height; while plant base diameter gave the lowest GCV (1.456\%), PCV (2.005\%), $h_{b}^{2}$ $(72.640 \%)$ and GAM (2.999\%) (Table 5). The highest $h_{b}^{2}$ (98.540\%) was found for dry fibre yield of the plants. All the characters exhibited high $h_{b}^{2}$ ranging from $72.640 \%$ in plant base diameter and $98.540 \%$ in dry fibre yield of the plant. The GA ranged from 0.113 in plant height to 5.158 in green weight with leaves of the plants. Among all the traits, the green weight with leaves and green weight without leaves of the plants exhibited higher GA while the other traits exhibited almost similar results except dry stick yield of the plants. The plant height and stem plant base diameter gave nearest results for GA in the percentage of the mean; where the highest GAM (\%) was observed in dry stick yield of the plants (19.265\%) and plant population (Lac ha $\left.{ }^{-1}\right)(16.049 \%)$. The morphological trait(s) having high $h_{b}^{2}$ viz. dry fibre and jute stick yield, green weight with leaves, green weight without leaves, the height of the plants would be considered as criteria for jute crop development, as previous reports (2). In this study, environmental factors (temperature, rainfall, drought

Table 3. Mean square values for seven yield and yield attributing traits of eight Tossa jute genotypes (ANOVA).

\begin{tabular}{lcccccccc}
\hline Sources of variation & DF & PP & PH & BD & GWL & GWL $_{1}$ & FY & STY \\
\hline Replication & 2 & 0.069 & 0.004 & 0.091 & 7.087 & 2.260 & 0.031 & 0.276 \\
\hline Genotype & 7 & $0.185^{* *}$ & $0.011^{* *}$ & $0.235^{\text {NS }}$ & $24.790^{*}$ & $17.874^{* *}$ & $0.069^{* *}$ & $2.181^{* *}$ \\
\hline Error & 14 & 0.03 & 0.002 & 0.111 & 5.980 & 2.239 & 0.002 & 0.306 \\
\hline Grand mean & & 2.916 & 2.929 & 13.960 & 44.781 & 33.948 & 2.871 & 8.454 \\
\hline CV (\%) & 6.05 & 1.38 & 2.39 & 5.46 & 4.41 & 1.58 & 6.54 \\
\hline 'P' value & 0.0023 & 0.0012 & 0.1116 & 0.0114 & 0.0005 & 0.0000 & 0.0010 \\
\hline Calculated 'F' value & 5.95 & 6.86 & 2.11 & 4.15 & 7.98 & 33.50 & 7.13 \\
\hline Tabulated 'F' value & & \multicolumn{7}{c}{$2.76(P \leq 0.05) ; 4.28(P \leq 0.01)$} \\
\hline
\end{tabular}

Note: DF=Degree of freedom; $C V$ (\%)-Coefficient of variation (\%); (PP, $P H, B D, G W L, G W L_{1}, F Y$, STY- see in Table 2). 
Table 4. Mean performance of eight Tossa jute genotypes for morphological characters.

\begin{tabular}{|c|c|c|c|c|c|c|c|}
\hline Genotypes & $\mathbf{P P}$ & PH & BD & GWL & $\mathbf{G W L}_{1}$ & FY & STY \\
\hline $\mathrm{G}_{1}$ & $2.78^{b}$ & $2.95^{\mathrm{a}}$ & 14.20 & $48.03^{\mathrm{ab}}$ & $34.58^{\mathrm{bc}}$ & $2.94^{b}$ & $8.01^{\mathrm{bc}}$ \\
\hline $\mathrm{G}_{2}$ & $3.32^{\mathrm{a}}$ & $2.96^{\mathrm{a}}$ & 13.82 & $48.98^{\mathrm{a}}$ & $38.52^{\mathrm{a}}$ & $3.12^{\mathrm{a}}$ & $10.31^{\mathrm{a}}$ \\
\hline $\mathrm{G}_{3}$ & $3.01^{\mathrm{ab}}$ & $2.86^{\mathrm{b}}$ & 13.63 & $42.37^{\mathrm{cd}}$ & $32.79^{\text {cde }}$ & $2.78^{\mathrm{c}}$ & $8.81^{b}$ \\
\hline $\mathrm{G}_{4}$ & $2.78^{\mathrm{bc}}$ & $2.97^{\mathrm{a}}$ & 14.03 & $43.05^{\mathrm{cd}}$ & $31.10^{\mathrm{e}}$ & $2.76^{\mathrm{c}}$ & $7.99^{\mathrm{bc}}$ \\
\hline $\mathrm{G}_{5}$ & $2.94^{\mathrm{b}}$ & $2.85^{b}$ & 13.74 & $44.25^{\text {bcd }}$ & $34.51^{\mathrm{bcd}}$ & $2.83^{c}$ & $8.74^{\mathrm{b}}$ \\
\hline $\mathrm{G}_{6}$ & $2.47^{\mathrm{c}}$ & $2.98^{\mathrm{a}}$ & 14.51 & $45.08^{\mathrm{abc}}$ & $31.94^{\mathrm{de}}$ & $2.79^{c}$ & $7.63^{c}$ \\
\hline $\mathrm{G}_{7}$ & $3.04^{\mathrm{ab}}$ & $3.00^{\mathrm{a}}$ & 13.92 & $46.05^{\mathrm{abc}}$ & $35.89^{\mathrm{b}}$ & $3.05^{\mathrm{a}}$ & $8.21^{b c}$ \\
\hline $\mathrm{G}_{8}$ & $3.00^{\mathrm{b}}$ & $2.86^{\mathrm{b}}$ & 13.83 & $40.44^{\mathrm{d}}$ & $32.25^{\text {cde }}$ & $2.68^{\mathrm{d}}$ & $7.93^{\mathrm{bc}}$ \\
\hline Maximum & 3.32 & 3.00 & 14.51 & 48.98 & 38.52 & 3.12 & 10.31 \\
\hline Minimum & 2.47 & 2.85 & 13.63 & 40.44 & 31.10 & 2.68 & 7.63 \\
\hline Mean & 2.92 & 2.93 & 13.96 & 44.78 & 33.95 & 2.87 & 8.45 \\
\hline S.E ( \pm$)$ & 0.144 & 0.033 & 0.273 & 1.997 & 1.222 & 0.037 & 0.452 \\
\hline Std. Dev. & 0.248 & 0.061 & 0.280 & 2.875 & 2.441 & 0.152 & 0.853 \\
\hline $\operatorname{LSD}_{(0.05)}$ & $0.309^{* *}$ & $0.071^{* *}$ & $0.585^{\mathrm{NS}}$ & $4.283^{*}$ & $2.620^{* *}$ & $0.080^{* *}$ & $0.969 * *$ \\
\hline
\end{tabular}

Note: (PP, PH, BD, GWL, GWL,$F Y$, STY- see in Table 2); $\left(G_{1}, G_{2}, G_{3}, G_{4}, G_{5}, G_{6}, G_{7}, G_{8}-\right.$ see in Table 1); S. E=Standard error, LSD (0.05) $=$ Least significant differences among the treatments at 0.05 probability level, NS=Non significant, * \& ** denote significant at 0.05 and 0.01 probability level, Values with different letter(s) are statistically significant within the same column.

Table 5. Genetic parameters for seven different morphological characters among eight Tossa jute genotypes.

\begin{tabular}{|c|c|c|c|c|c|c|c|c|c|}
\hline Traits & $\bar{X}$ & $\mathrm{GV}\left(\sigma_{\mathrm{G}}^{2}\right)$ & $\operatorname{PV}\left(\sigma_{P}^{2}\right)$ & GCV (\%) & PCV (\%) & ECV (\%) & $h_{b}^{2}(\%)$ & GA & GAM (\%) \\
\hline PP & 2.916 & 0.052 & 0.062 & 7.795 & 8.516 & 5.940 & 91.533 & 0.468 & 16.049 \\
\hline $\mathrm{PH}$ & 2.929 & 0.003 & 0.004 & 1.870 & 2.067 & 1.527 & 90.453 & 0.113 & 3.873 \\
\hline BD & 13.961 & 0.041 & 0.078 & 1.456 & 2.005 & 2.387 & 72.640 & 0.419 & 2.999 \\
\hline GWL & 44.781 & 6.270 & 8.263 & 5.592 & 6.419 & 5.461 & 87.108 & 5.158 & 11.519 \\
\hline $\mathrm{GWL}_{1}$ & 33.948 & 5.212 & 5.958 & 6.725 & 7.190 & 4.408 & 93.527 & 4.703 & 13.852 \\
\hline FY & 2.871 & 0.022 & 0.023 & 5.205 & 5.282 & 1.558 & 98.540 & 0.309 & 10.751 \\
\hline STY & 8.454 & 0.625 & 0.727 & 9.351 & 10.086 & 6.543 & 92.720 & 1.629 & 19.265 \\
\hline
\end{tabular}

Note: (PP, PH, BD, GWL, GWL $, F Y, S T Y$ - see in Table 2$) ; \bar{X}=$ Grand mean value of the variable, GV ( $\left.\sigma_{P}^{2}\right)$-Genotypic variation, $P V\left(\sigma_{P}^{2}\right)$ Phenotypic variation, GCV-Genotypic coefficient of variation, PCV-Phenotypic coefficient of variation, ECV-Environmental coefficient of variation, $h_{b s}^{2}$-Heritability in the broad sense, GA-Genetic advance, GAM (\%)-Genetic advance as a percentage of the mean.

etc.) showed lower influences on the expression of genes for morphological traits and the possibility of high genetic gain; which was ensured from the least difference between the PCV and GCV values for these traits (44). The estimation of heritability in the broad sense for morphological traits is essential for the breeders regarding the plant selection for phenotypic performance. An estimate of heritability, genetic advance and genetic advance (\%) of mean for the studied characters explore the extent of possible advancement in phenotypic selection expected (31).

\section{Association among the morphological traits}

\section{Estimation of Pearson correlation}

Pearson correlation coefficients among all the characters in all possible combinations were assessed (Table 6) according to an earlier research procedure (30). Plant population (Lac ha $\mathrm{ha}^{-1}$ ) correlated significantly with plant base diameter $\left(\mathrm{r}=-0.471^{* *}\right)$ and green weight with leaves $\left(r=0.353^{*}\right)$ and highly significant with dry fibre yield $\left(\mathrm{r}=0.484^{* *}\right)$ and jute stick yield $\left(\mathrm{r}=0.558^{* *}\right)$; the plant height significantly correlated with green weight without leaves $\left(r=0.346^{*}\right)$ and highly significant with plant base diameter $\left(\mathrm{r}=0.634^{* *}\right)$, green weight with leaves $\left(\mathrm{r}=0.554^{* *}\right)$ and jute fibre yield $\left(\mathrm{r}=0.523^{* *}\right)$. Stem base diameter correlated significantly with plant population $\left(\mathrm{r}=0.471^{* *}\right)$, green weight with leaves $\left(\mathrm{r}=0.286^{*}\right)$ and jute stick yield $\left(\mathrm{r}=-0.305^{*}\right)$ and highly significant with plant height $\left(\mathrm{r}=0.634^{* *}\right)$. The green weight with leaves associated significantly with plant population $\left(\mathrm{r}=0.353^{*}\right)$ and plant base diameter $(\mathrm{r}=$ $0.286^{*}$ ) and highly significant with plant height $\left(\mathrm{r}=0.554^{* *}\right)$, green weight without leaves $\left(\mathrm{r}=0.787^{* *}\right)$ and jute fibre yield $\left(\mathrm{r}=0.744^{* *}\right)$. The green weight with leaves showed significant association with plant height $\left(\mathrm{r}=0.346^{*}\right)$ and jute stick yield $\left(\mathrm{r}=0.288^{*}\right)$, and strong relation with plant population $\left(\mathrm{r}=0.711^{* *}\right)$, green weight with leaves $\left(\mathrm{r}=0.787^{* *}\right)$ and jute fibre yield $\left(\mathrm{r}=0.744^{* *}\right)$. The jute fibre yield was associated strongly with plant population $\left(\mathrm{r}=0.484^{* *}\right)$, the height of plant $\left(\mathrm{r}=0.523^{* *}\right)$, plant weight with green leaves $\left(\mathrm{r}=0.744^{* *}\right)$, plant weight without green leaves $\left(\mathrm{r}=0.822^{* *}\right)$ and jute stick yield $\left(\mathrm{r}=0.484^{* *}\right)$. The jute stick yield was correlated highly significant with plant population $\left(\mathrm{r}=0.558^{* *}\right)$, green weight without leaves $\left(\mathrm{r}=0.544^{* *}\right)$ and significantly with plant base diameter $\left(\mathrm{r}=-0.305^{*}\right)$, green weight with leaves $\left(\mathrm{r}=0.288^{*}\right)$, jute fibre yield $\left(\mathrm{r}=0.484^{* *}\right)$.

\section{Genotypic and phenotypic correlations}

Genotypic and phenotypic correlations were partitioned and estimated for seven phenological characters (Table 7). At both genetic and phenotypic levels, all the traits except plant base diameter showed significant correlations with dry fibre yield. Except for plant height, significantly associated with jute stick yield; where plant base diameter and dry stick yield gave negative strong significant relation. Highly significant and positive correlations were found among plant population $\left(\mathrm{Lac} \mathrm{ha}^{-1}\right)$ with green weight without leaves $\left(r_{g}=0.835^{* *}, r_{p}=0.715^{* *}\right)$, dry fibre yield $\left(\mathrm{r}_{\mathrm{g}}=0.583^{* *}, \mathrm{r}_{\mathrm{p}}=0.522^{* *}\right)$ and dry stick yield $\left(r_{g}=0.958^{* *}, r_{p}=0.813^{* *}\right)$ of the plants. This indicated that, the plant population per unit area contributed significantly towards fibre yield of the jute plant. Plant population showed a negative correlation with plant base diameter $\left(r_{g}=-0.781^{* *}, r_{p}=\right.$ $-0.809 * *)$ indicating that the jute plant base diameter 
Table 6. Pearson correlations among yield and yield attributing traits of eight Tossa jute genotypes.

\begin{tabular}{lccccc}
\hline Characters & PP & PH & BD & GWL & GWL1 \\
\hline PP & 1.000 & & & & \\
\hline PH & -0.043 & 1.000 & & & \\
\hline BD & $-0.471^{*}$ & $0.634^{* *}$ & 1.000 & 1.000 & \\
\hline GWL & $0.353^{*}$ & $0.554^{* *}$ & $0.286^{*}$ & $0.787^{* *}$ & 1.000 \\
\hline GWL & $0.711^{* *}$ & $0.346^{*}$ & -0.018 & $0.744^{* *}$ & $0.822^{* *}$ \\
\hline FY & $0.484^{* *}$ & $0.523^{* *}$ & 0.003 & $0.288^{*}$ & $0.544^{* *}$
\end{tabular}

Note: PP, PH, BD, GWL, GWL,$F Y$, STY- see in Table 2; * and ** denote significantly correlated and strongly significant association; Positive ‘+’ correlation means both variable will be increased or decreased, but negative '-' correlation means vice-versa relation.

decreased with increasing the plant population per unit area. The Plant height showed highly significant and positive correlations with plant base diameter $\left(r_{\mathrm{g}}=0.923^{* *}, \mathrm{r}_{\mathrm{p}}=0.580^{* *}\right)$, green weight with leaves $\left(\mathrm{r}_{\mathrm{g}}=0.770^{* *}, \mathrm{r}_{\mathrm{p}}=0.581^{* *}\right)$ and dry fibre yield $\left(\mathrm{r}_{\mathrm{g}}=\right.$ $\left.0.648^{* *}, \quad r_{p}=0.549^{* *}\right)$ at both phenotypic and genotypic levels indicating that plant base diameter and yield components will be increased with increasing the height of plants.

\section{Euclidean Cluster Analysis}

The eight Tossa jute genotypes were grouped into three major clusters at the genetic distance of 3.0 in cluster analysis (Table 8, Fig. 2) using all variables indicating the notable genetic divergence among all genotypes for their morphological traits. The clustering Dendrogram grouped the jute genotypes having similar morphological characters into the same cluster. In cluster analysis, the cluster III was larger consisting of $50 \%$ jute genotypes including three breeding lines and one control variety $\left(\mathrm{G}_{8}\right)$ and the second-largest group (cluster I) consisting of $37.50 \%$ genotypes including two breeding lines and control variety $\left(\mathrm{G}_{7}\right)$. The last group was the cluster II containing $12.50 \%$ genotype the superior breeding line or genotype $\left(\mathrm{G}_{2}\right)$. In PCA, $99.63 \%$ variation was observed for the first five principal components among the total variation. The genotype (s) of the cluster having more genetic distances would be used as breeding parents to develop new high yielding Tossa jute varieties with more significant heterosis content for the desired traits. Clustering Dendrogram and two-dimensional PCA graph indicated that the line $\left(\mathrm{G}_{2}\right)$ made its cluster (II), and more distant from the other clusters. Therefore, this true breeding line having more diversity would be used as breeding material or/for the varietal development programme of Tossa jute in Bangladesh.

\section{Estimation of means of all clusters for the characters studied}

Average values of different morphological traits of eight Tossa jute genotypes in three different clusters were estimated (Table 9). The cluster II recorded the highest mean values for all traits except girth of the plants followed by clusters-I; while, the cluster III revealed the lowest means for all the traits. The cluster II having high mean value $(2.965 \mathrm{~m})$ followed by cluster I $(2.933 \mathrm{~m})$ and Cluster III $(2.917 \mathrm{~m})$ for the height of plants. The cluster III having high mean value $(14.00 \mathrm{~mm})$ followed by cluster I (13.954 mm) and cluster II $(13.820 \mathrm{~mm})$ for the girth of plants. The mean values for green weight with leaves of the plants were high (48.976 t ha-1), medium (46.112 t ha ${ }^{1}$ ) and low (42.734 $\mathrm{t} \mathrm{ha}^{-1}$ ) in cluster II, I and III, respectively. Similarly, for green weight without leaves, cluster II (38.518 t ha-1) followed by cluster I (34.993 t ha-1) and cluster III (32.022 t ha $\mathrm{t} \mathrm{h}^{-1}$ ). For dry fibre yield, cluster II (3.122 $\left.\mathrm{t} \mathrm{ha}^{-1}\right)$ followed by cluster I (2.941 t ha $\left.{ }^{-1}\right)$ and cluster III (2.755 t ha-1) and for dry stick weight cluster II (10.312 $\left.\mathrm{t} \mathrm{ha} \mathrm{ha}^{-1}\right)$ followed by cluster I (8.321 tha-1) and III (8.090 t ha-1).

\section{Estimation of cluster distances $\left(D^{2}\right)$}

The average inter- and intra-cluster distances among all jute genotypes were assessed (Fig. 3). The higher inter-cluster distance (9.302) was recorded between the cluster II and III; while minimum distance (4.510) between cluster I and II. The intra cluster distances were recorded 4.411, 0.000 and 4.635 for cluster I, II and III, respectively (Fig. 3).

\section{Analyses of Principal Component (PCA)}

Analyses of principal components for genetic diversity among all jute genotypes were performed

Table 7. Partitioning of Genotypic and phenotypic correlation coefficients among seven morphological traits.

\begin{tabular}{|c|c|c|c|c|c|c|c|}
\hline Characters & Correlations & PH & BD & GWL & GWL1 & FY & STY \\
\hline \multirow{2}{*}{$\mathrm{PP}$} & $\mathrm{r}_{\mathrm{g}}$ & -0.223 & $-0.781^{* *}$ & 0.225 & $0.835^{* *}$ & $0.583^{* *}$ & $0.958^{* *}$ \\
\hline & $\mathrm{r}_{\mathrm{p}}$ & -0.177 & $-0.809^{* *}$ & 0.180 & $0.715^{* *}$ & $0.522^{* *}$ & $0.813^{* *}$ \\
\hline \multirow{2}{*}{$\mathrm{PH}$} & $r_{g}$ & & $0.923^{* *}$ & $0.770^{* *}$ & $0.292^{*}$ & $0.648^{* *}$ & -0.087 \\
\hline & $\mathrm{r}_{\mathrm{p}}$ & & $0.580^{* *}$ & $0.581^{* *}$ & 0.236 & $0.549^{* *}$ & -0.070 \\
\hline \multirow{2}{*}{$\mathrm{BD}$} & $r_{g}$ & & & $0.463^{*}$ & $0.425^{*}$ & 0.065 & $-0.844^{* *}$ \\
\hline & $\mathrm{r}_{\mathrm{p}}$ & & & $0.292^{*}$ & $0.288^{*}$ & 0.046 & $-0.567^{* *}$ \\
\hline \multirow{2}{*}{ GWL } & $r_{g}$ & & & & $0.946^{* *}$ & $0.954^{* *}$ & $0.568^{* *}$ \\
\hline & $\mathrm{r}_{\mathrm{p}}$ & & & & $0.771^{* *}$ & $0.891^{* *}$ & $0.459^{* *}$ \\
\hline \multirow{2}{*}{ GWL1 } & $r_{g}$ & & & & & $0.988^{* *}$ & $0.899^{* *}$ \\
\hline & $\mathrm{r}_{\mathrm{p}}$ & & & & & $0.926^{* *}$ & $0.779^{* *}$ \\
\hline \multirow{2}{*}{ FY } & $r_{g}$ & & & & & & $0.685^{* *}$ \\
\hline & $\mathrm{r}_{\mathrm{p}}$ & & & & & & $0.622^{* *}$ \\
\hline
\end{tabular}

Note: PP, $P H, B D, G W L, G W L_{1}, F Y$, STY- see in Table 2; $r_{g}=$ Genotypic correlation and $r_{p}=$ Phenotypic correlation; The Values between 0.5 to 1.0 or -1.0 to -0.5 denote strong correlation**, and values between -0.5 to -0.3 or 0.3 to 0.5 denote moderate correlation*; and others values denote weak or very weak/non-significant correlation. 
Table 8. Cluster groups of jute genotypes with their percentages.

\begin{tabular}{cccc}
\hline Cluster & No. of genotypes & Percentage & Genotypes \\
\hline I & 3 & 37.50 & $\mathrm{G}_{7}, \mathrm{G}_{5}, \mathrm{G}_{1}$ \\
\hline II & 1 & 12.50 & $\mathrm{G}_{2}$ \\
\hline III & 4 & 50.00 & $\mathrm{G}_{4}, \mathrm{G}_{3}, \mathrm{G}_{8}, \mathrm{G}_{6}$ \\
\hline 3 Clusters & 8 Genotypes & $100 \%$ & 8 Genotypes \\
\hline
\end{tabular}

Note: $G_{1}, G_{2}, G_{3}, G_{4}, G_{5}, G_{6}, G_{7}, G_{8}$ - see in Table 1 .

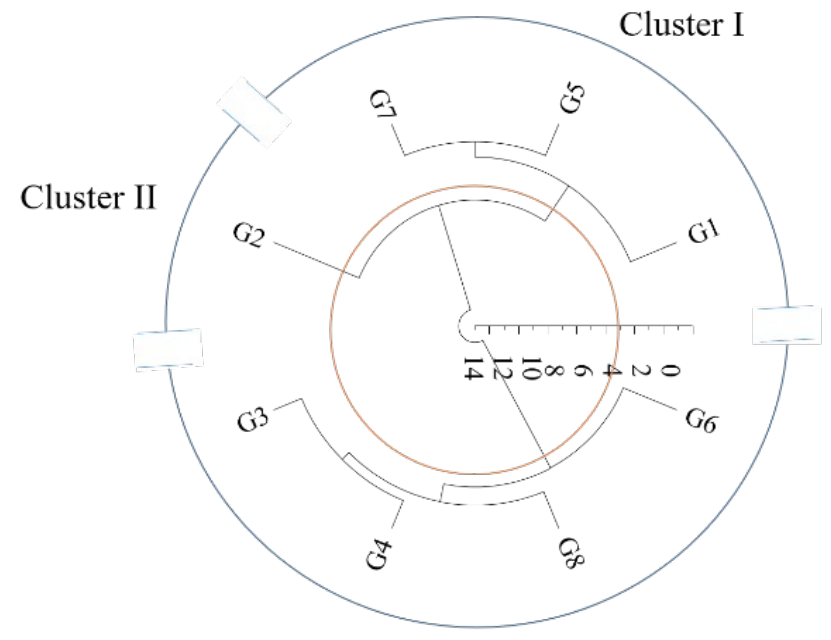

Cluster III

Fig. 2. Dendrogram showing the relationships among eight tossa jute genotypes for seven morphological characters.

Note: $G_{1}, G_{2}, G_{3}, G_{4}, G_{5}, G_{6}, G_{7}, G_{8}$ - see in Table 1

for all morphological traits studied. The cluster analysis was mostly confirmed by the PCA. The eigenvalues, variabilities and cumulative variabilities among the principal components in PCA analyses were shown in Table 10 and scree plot analysis (Fig. 4). The variabilities increased with increasing the eigenvalues, but the variation in cumulative variabilities is vice-versa (Fig. 4). In this analysis, the first two principal components having Eigenvalues $>1.0$, accounting for $90.88 \%$ of total variations. The first principal component recorded variations about 55.740\%; while the second $35.144 \%$, third $5.124 \%$, fourth $2.682 \%$ and fifth $0.944 \%$ of the total variations (Table 10). In PCA, the tested lines were categorized into five groups based on seven morphological variables (Fig. 5, 6). The breeding line $\mathrm{G}_{5}$ formed one group (Group I) in PCA and Cluster III under cluster analysis. In PCA, the lines of cluster I namely, $G_{4}$ and $G_{6}$ formed the group II. The lines $G_{1}$ and $\mathrm{G}_{7}$ of cluster III under cluster analysis formed the group III in PCA. The group IV consisted of the lines $\mathrm{G}_{3}$ and $\mathrm{G}_{8}$ under PCA and cluster I under cluster analysis. The superior breeding line $G_{2}$ formed its individual cluster (Cluster II) in cluster analysis and individual group (Group V) in PCA (Fig. 2, 5, 6). In the $1^{\text {st }}$ principal component, all the traits except base diameter recorded positive values; where, plant height and base diameter showed low vector values, and the other characters showed high vector values (Table 11). In the $2^{\text {nd }}$ principal component, all the traits except plant population and dry stick yield recorded positive values; and plant height and base diameter showed high vector values. Further, in the $3^{\text {rd }}$ principal component, plant population, plant height and fibre yield showed positive values and the other traits recorded negative values; were plant height recorded high vector value. In $4^{\text {th }}$ principal component, base diameter and stick yield showed positive values and other traits showed negative values; and the highest value was found in dry stick yield. The plant population, base diameter and green weight without leaves recorded positive vector values where, base diameter showed high values; and other traits recorded negative values in the last principal component (Table 11).

\section{Discussion}

The studied characters of jute plants showed significant variance indicating the extent of genetic variability present among the jute genotypes. Analyses of mean square values indicated that the genotypes were highly significant $(P \leq 0.01)$ for the plant population (Lac $\mathrm{ha}^{-1}$ ), plant height (m), green

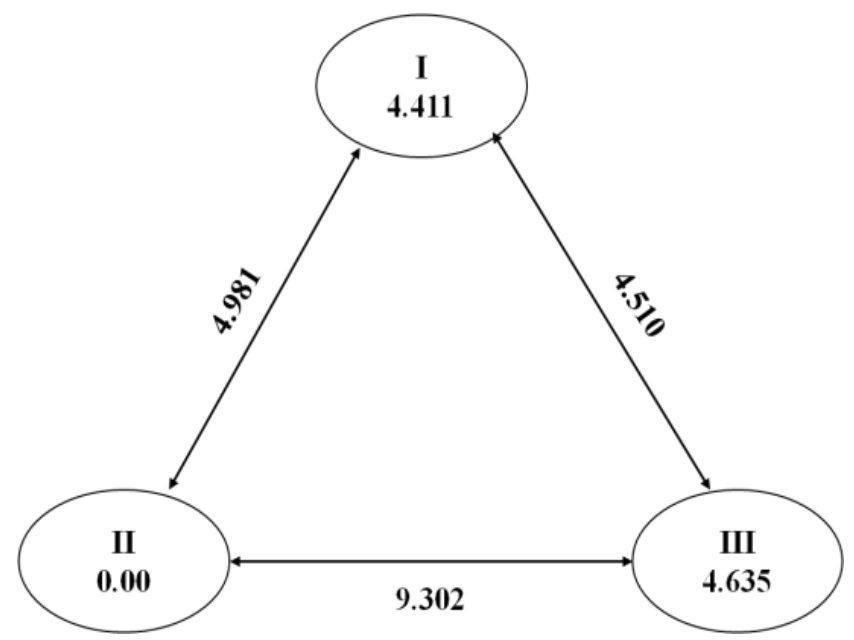

Fig. 3. Average intra and inter cluster distances for seven morphological characters of 8 tossa jute genotypes.

weight without leaves ( $\mathrm{t} \mathrm{ha} \mathrm{a}^{-1}$ ), dry fibre yield (t ha-1) and dry stick yield ( $\left.\mathrm{t} \mathrm{ha}^{-1}\right)$; and significant $(P \leq 0.05)$

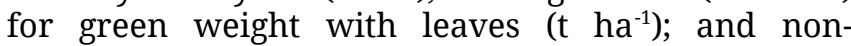
significant for base diameter ( $\mathrm{mm})$. In earlier, significant variations were described for various morphological traits in jute plants $(12,45)$. From the mean performance, it can be said undoubtedly that, the $G_{2}$ was good genotype for yield and yield attributing traits than the control varieties among all the Tossa jute genotypes. All breeding lines performed better for fibre yield and yield attributes than control $\left(\mathrm{G}_{8}\right)$ except another one $\left(\mathrm{G}_{7}\right)$; where, the line $G_{2}$ was superior to both controls. These results agreed with the results of an earlier study (46).

The highest GV, PV components (\%), GA and grand mean were $(6.270,8.263 ; 5.158,44.781)$ recorded for green weight with leaves of the plants. The GCVs were higher than the respective PCVs for all morphological characters. The dry stick yield of the plant showed the highest GCV (9.351\%), PCV (10.086\%), ECV (6.543\%) and GAM (19.265\%). The lowest GV, PV, ECV (\%) and were GA $(0.003,0.004$, 
Table 9. Average values of morphological characters in different clusters.

\begin{tabular}{|c|c|c|c|c|}
\hline Characters & Cluster I & Cluster II & Cluster III & Mean \\
\hline Plant population (Lac ha-1) & 2.918 & 3.317 & 2.813 & 3.016 \\
\hline Plant height (m) & 2.933 & 2.965 & 2.917 & 2.938 \\
\hline Stem base diameter (mm) & 13.954 & 13.820 & 14.000 & 13.925 \\
\hline Plant weight with green leaves (t ha ${ }^{-1}$ ) & 46.112 & 48.976 & 42.734 & 45.941 \\
\hline Plant weight without green leaves $\left(\mathrm{t} \mathrm{ha}^{-1}\right)$ & 34.993 & 38.518 & 32.022 & 35.178 \\
\hline Dry Fibre yield $\left(\mathrm{t} \mathrm{ha}^{-1}\right)$ & 2.941 & 3.122 & 2.755 & 2.939 \\
\hline Dry Stick yield (t ha $\left.{ }^{-1}\right)$ & 8.321 & 10.312 & 8.090 & 8.908 \\
\hline
\end{tabular}

Table 10. Eigenvalues, Variability and Cumulative variability among the components in PCA.

\begin{tabular}{lcccccccc}
\hline \multirow{2}{*}{ Eigenvalues: } & \multicolumn{5}{c}{ Components } \\
\cline { 2 - 7 } & 1 & 2 & 3 & 4 & 5 & 0.066 & 0.024 \\
\hline Eigenvalue & 3.902 & 2.460 & 0.359 & 0.188 & 0.002 \\
\hline Variability (\%) & 55.740 & 35.144 & 5.124 & 2.682 & 0.944 & 0.341 \\
\hline Cumulative \% & 55.740 & 90.884 & 96.008 & 98.690 & 99.634 & 99.975 & 100.000 \\
\hline
\end{tabular}

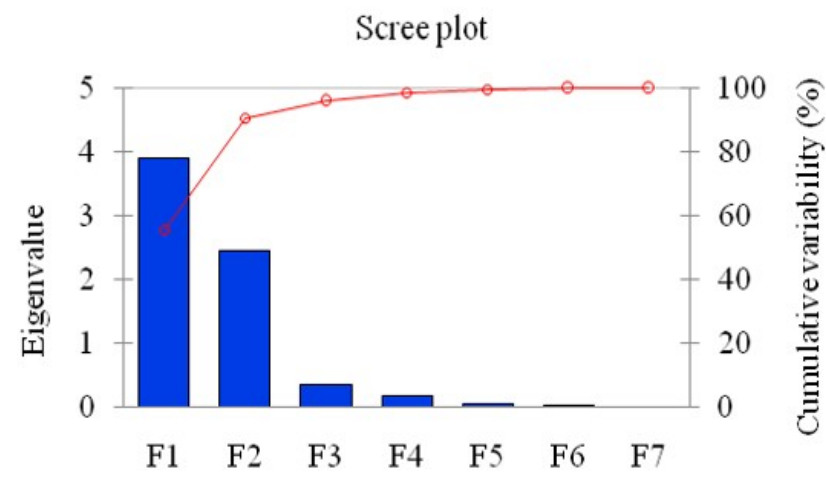

Factors (Components)

Fig. 4. Eigenvalues and cumulative variabilities in PCA scree plot.

$1.527,0.103)$ recorded for plant height; plant base diameter gave the lowest GCV (\%), PCV (\%), $h_{b}^{2}(\%)$ and GAM (\%) were (1.456, 2.005, 72.640, 2.999) recorded for the highest $h_{b}^{2}(98.540 \%)$ was found for dry fibre yield of the plants. The morphological trait(s) having high $h_{b}^{2}$ viz. dry fibre and jute stick yield, green weight with leaves, green weight without leaves, the height of the plants would be considered as criteria for jute crop development, similar to an earlier study (2). Environmental factors (drought, temperature, rainfall etc.) showed lower influences on the expression of genes for morphological traits and the possibility of high genetic gain; which was ensured from the less differences between the PCV and GCV values for these traits (44). It is so important to the breeders to estimate the $h_{b}^{2}$ for morphological traits for the plant selection for phenotypic performance. The estimate of heritability, genetic advance and genetic advance (\%) of the mean for the studied characters explore the extent of possible

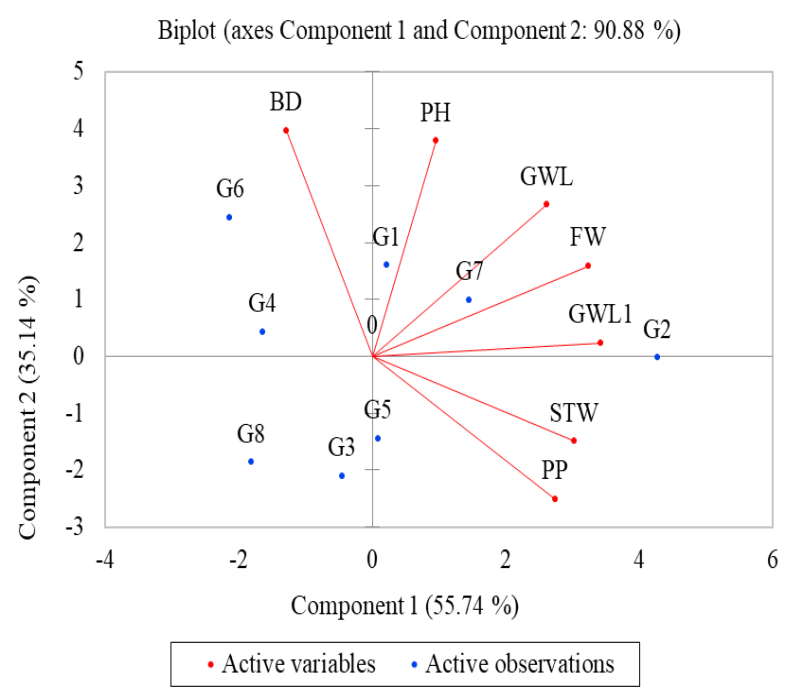

Fig. 5. Two-dimensional plot of PCA showing relationships among eight Tossa jute genotypes for seven morphological traits.

Note: $G_{1}, G_{2}, G_{3}, G_{4}, G_{5}, G_{6}, G_{7}, G_{8}$ - see in Table 1; $P P, P H, B D, G W L$, $G W L_{1}, F Y, S T Y-$ see in Table 2

advancement in phenotypic selection expected (30). So, the characters with high heritability values; and characters with high GCV \& GAM (\%) except plant height and plant base diameter would be used as phenotypic selection criteria for varietal improvement; and the high expected genetic gain would be achieved from a selection (47). It is also explained that these traits controlled by additive gene action and the continuous selection would be responded by these characters (17). High heritability with low GCV and GA (\%) for the rest of the traits like plant height and a base diameter of the plant stem indicated that, expression of these traits are controlled by non-additive gene actions, and not so effective tools for phenotypic selections (48). The positive and highly strong correlation between

Table 11. Vector components among the morphological traits studied.

\begin{tabular}{|c|c|c|c|c|c|}
\hline Plant traits & Vector-1 & Vector-2 & Vector-3 & Vector-4 & Vector-5 \\
\hline Plant population ( $\left.\mathrm{Lac} \mathrm{ha}^{-1}\right)$ & 0.394 & -0.361 & 0.372 & -0.063 & 0.457 \\
\hline Plant height (m) & 0.137 & 0.545 & 0.709 & 0.291 & -0.075 \\
\hline Stem base diameter $(\mathrm{mm})$ & -0.185 & 0.571 & -0.281 & 0.177 & 0.664 \\
\hline Plant weight with green leaves $\left(\mathrm{t} \mathrm{ha}^{-1}\right)$ & 0.377 & 0.383 & -0.427 & -0.083 & -0.367 \\
\hline Plant weight without green leaves $\left(\mathrm{t} \mathrm{ha}^{-1}\right)$ & 0.493 & 0.033 & -0.164 & -0.361 & 0.403 \\
\hline Dry Fibre yield $\left(\mathrm{t} \mathrm{ha}^{-1}\right)$ & 0.466 & 0.228 & 0.111 & -0.275 & -0.217 \\
\hline Dry Stick yield $\left(\mathrm{t} \mathrm{ha}^{-1}\right)$ & 0.435 & -0.216 & -0.242 & 0.816 & -0.014 \\
\hline
\end{tabular}


characters means that one will be increased corresponding to the increase of the other one and vice-versa in case of negative association. The

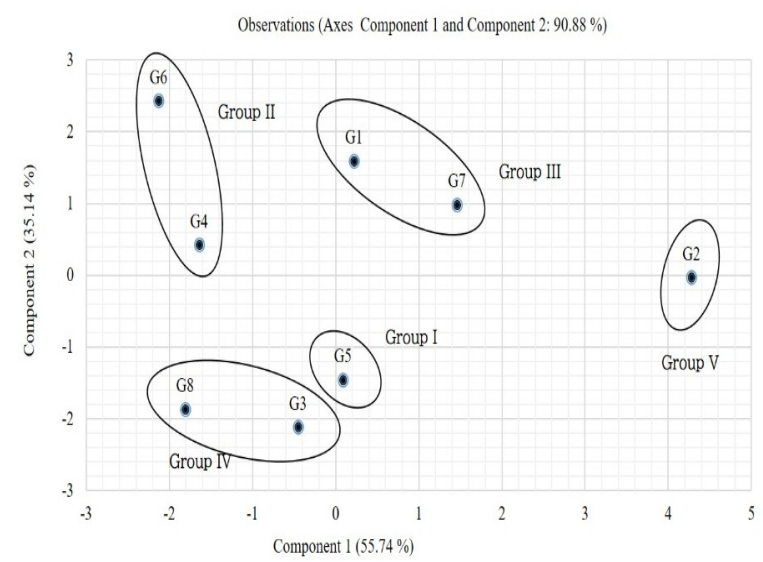

Fig. 6. PCA score plot showing relationships among eight Tossa jute genotypes.

Note: $G_{1}, G_{2}, G_{3}, G_{4}, G_{5}, G_{6}, G_{7}, G_{8}$ - see in Table 1 .

creation of variability in the morphological characters to develop new plant type having the higher yield potentiality and quality should be the main objectives of a plant breeder. In earlier, a researcher (2) reported that, the important yield attributing variables in jute plants are the plant population per unit area, the height of plant, girth, leaf size, shape, leaf angle, fresh weight of plants with green leaves, fresh weight without green leaves which indicate the yield performance. The morphological characters in jute plant showing strong association with each other would be considered for selection criteria in varietal development programme $(12,49)$.

In this study, all the morphological traits showed higher genotypic correlations than phenotypic correlations which is similar to an earlier research findings $(50,51)$. The strongly significant associations between two characters at genotypic level indicate the possibility of improvement of these traits at genotypic level; and accordingly for the phenotypic level also. The positive association between two traits means the increase in one trait the increase in another trait; accordingly the negative association means the vice versa relation for these traits. At both genotypic and phenotypic levels, highly significant and positive correlations were found among the plant population ( $\mathrm{L} \mathrm{ha}^{-1}$ ) with green weight without leaves $\left(r_{\mathrm{g}}=0.835^{* *}, \mathrm{r}_{\mathrm{p}}=0.715^{* *}\right)$, dry fibre yield $\left(0.583^{* *}, 0.522^{* *}\right)$ and dry stick yield $\left(0.958^{* *}\right.$, $0.813^{* *}$ ) of the plants indicating that the plant population per unit area contributed to increase jute fiber yield; and it is negatively correlated with plant base diameter $\left(-0.781^{* *},-0.809^{* *}\right)$ depicting the jute plant base diameter decreased with increasing the plant population per unit area; it was reported in earlier by some researchers (48). Plant height showed highly significant and positive correlations with plant base diameter $\left(\mathrm{r}_{\mathrm{g}}=0.923^{* *}, \mathrm{r}_{\mathrm{p}}=0.580^{* *}\right)$, green weight with leaves $\left(\mathrm{r}_{\mathrm{g}}=0.770^{* *}, \mathrm{r}_{\mathrm{p}}=0.581^{* *}\right)$, dry fibre yield $\left(\mathrm{r}_{\mathrm{g}}=0.648^{* *}, \mathrm{r}_{\mathrm{p}}=0.549^{* *}\right)$ at both phenotypic and genotypic levels and significantly related with green weight without leaves $\left(r_{g}=0.292^{*}\right)$ at genotypic level indicating that plant base diameter and yield components will be increased with increasing the height of jute plants (52). The plant base diameter showed highly significant and negative correlations with dry stick yield $\left(r_{\mathrm{g}}=-0.844^{* *}, \mathrm{r}_{\mathrm{p}}=-0.567^{* *}\right)$ indicating that, the dry stick yield will not be improved with increasing the plant base diameter. The diameter of the jute plants significantly associated with green weight of the plants with leaves $\left(r_{\mathrm{g}}=0.463^{*}, \mathrm{r}_{\mathrm{p}}=0.292^{*}\right)$ and without leaves $\left(\mathrm{r}_{\mathrm{g}}=0.425^{*}, \mathrm{r}_{\mathrm{p}}=0.288^{*}\right)$ indicating that green weight of jute plants would be increased with increasing the plant base diameter (53). The jute plant weight with green leaves showed highly significant positive correlations with green weight without leaves $\left(\mathrm{r}_{\mathrm{g}}=0.946^{* *}, \mathrm{r}_{\mathrm{p}}=0.771^{* *}\right)$, dry fibre yield $\left(\mathrm{r}_{\mathrm{g}}=0.954^{* *}\right.$, $\left.\mathrm{r}_{\mathrm{g}}=0.891^{* *}\right)$ and dry stick yield $\left(\mathrm{r}_{\mathrm{g}}=0.568^{* *}, \mathrm{r}_{\mathrm{p}}=0.459^{* *}\right)$ at both genotypic and phenotypic levels depicting that the more green weight of the plants improve the yield components of the jute genotypes which was supported by an earlier research findings (53). Highly significant and positive correlations were found in green weight without leaves of jute plant with its dry fibre yield $\left(\mathrm{r}_{\mathrm{g}}=0.988^{* *}, \mathrm{r}_{\mathrm{p}}=0.926^{* *}\right)$ and dry stick yield $\left(\mathrm{r}_{\mathrm{g}}=0.899 * *, \quad \mathrm{r}_{\mathrm{p}}=0.779 * *\right)$ at both genotypic and phenotypic levels. So, more the green weight of jute plants without green leaves more the dry fiber yield components, and it was found in an earlier research works (46). The dry fibre yield recorded highly significant and positive relations with all traits, but not significantly associated to plant base diameter which may be due to additive gene effects on the plant jute biology. Highly strong associations among the morphological traits would be considered as criteria for jute plant development through breeding approaches $(12,49)$.

The notable genetic variation for morphological traits exhibited by the selected jute genotypes were found from their clustering based on the Euclidean distances (44). The last group was the cluster II containing $12.50 \%$ of total genotype the superior breeding line or genotype $\mathrm{G}_{2}=0-0412-9-4$ (red). In total variation among the genotypes estimated in PCA, the $1^{\text {st }}$ five principal components recorded 99.63\% variation. The Euclidean clustering and analyses of principal components for the studied morphological characters of the genotypes played important role with lowering the inconsistencies in grouping them to measure their genetic variability as well as diversity (44). Dendrogram and twodimensional PCA graph indicated that the line $\mathrm{G}_{2}=\mathrm{O}$ 0412-9-4 (red) made its individual cluster (clusters II) and were distant from the other clusters. Therefore, the true breeding line of cluster II would be used as breeding material for varietal development of Tossa jute in Bangladesh. Similar findings were reported in soybean plant (44). Jute fibre yield is more important because it is directly associated with fibre fineness. For dry fibre yield, cluster II (3.122 $\left.\mathrm{t} \mathrm{ha}^{-1}\right)$ followed by cluster I (2.941 t ha-1) and cluster III (2.755 t ha-1) and for dry stick weight cluster II (10.312 $\left.\mathrm{t} \mathrm{ha}^{-1}\right)$ followed by cluster I (8.321 $\left.\mathrm{t} \mathrm{ha}^{-1}\right)$ and III $\left(8.090 \mathrm{t} \mathrm{ha}^{-1}\right)$. In earlier, some researchers $(52,53)$ found similar findings while working on jute crops during 2011, 2014. The higher distances among the clusters showed higher genetic divergences among the 
respective genotypes during the estimation of genetic diversity in jute crops $(52,54)$. The Tossa jute genotypes having higher genetic divergence and maximum values for fibre yield contents would be used to develop heterotic hybrids as well as the development of good segregating lines from different generations for higher quality fibre yield. In clustering, the cluster III showed higher distance (4.635) indicating the highest variation among jute genotypes in the cluster, while the cluster-I gave lower distance (4.411) depicting the lower variation among the genotypes in that cluster. The wide genetic diversity was recorded among the genotypes of different clusters than those of the same cluster because, the average inter-cluster distances were higher than intra cluster distances (46). The first two components in PCA showed higher Eigenvalues $(>1.0)$, cumulative variation of $90.88 \%$ among the experimental jute genotypes for studied morphological characters. These two components played important role for the variations as well as divergence among all genotypes. These results were corroborated with the findings of some researchers from in earlier studies during the estimation of PCA for genetic divergence in jute crops $(52,55)$. The tested lines were categorized into five groups in PCA. The breeding line $\mathrm{G}_{5}=0-0419-3-1$ (Red) formed one group (Group I) in PCA analysis and Cluster III under cluster analysis. In PCA analysis, the lines of cluster I namely, $\mathrm{G}_{4}=0-049-1-3$ (Red) and $\mathrm{G}_{6}=0-043-7-9$ (Red) formed the group II. The lines $\mathrm{G}_{1}=0-0512-6-2$ (green) and $\mathrm{G}_{7}=$ BJRI Tossa pat-8 (Robi-1) of cluster III under cluster analysis formed the group III in PCA analysis. The group IV consisted of the lines $\mathrm{G}_{3}=0-0411-10-4$ (Red) and $\mathrm{G}_{8}=\mathrm{JRO}-524$ under PCA analysis and cluster I under cluster analysis. The superior breeding line $\mathrm{G}_{2}=$ 0-0412-9-4 (red) formed its cluster (Cluster II) in cluster analysis and individual group (Group V) in PCA analyses. The jute morphological characters showing high vector values were closer to one within the given principal component and effected the cluster more than the variables showing low vector values closer to zero; it was supported by the earlier studies (55). In the $1^{\text {st }}$ principal component, all the traits except base diameter recorded positive values; where, plant height and base diameter showed low vector values, and the other characters showed higher values (Table 11), it was described earlier by some researchers $(54,55)$. In the case of second principal component, all the traits except plant population and dry stick yield recorded positive values; and plant height and base diameter showed high vector values.

\section{Conclusion}

The height of the jute plant, number of plants per unit area, green weight of the plants and jute fibre yield showed strongly significant association with each other at both genotypic and phenotypic levels indicating that these traits would be used as selection criteria in breeding system. These traits also showed high heritability in broad sense coupled with higher genetic advance, higher genotypic coefficient of variation and phenotypic coefficient of variation; so these traits would be considered for increasing the genetic gain as well as phenotypic selection criteria for varietal development in Tossa Jute. Creation of variability and development of new genotypes from the existing population with improvement in plant traits is the main objective of plant breeding. This investigation revealed the presence of substantial variations for fibre yield and yield attributes among the newly developed jute breeding lines than the control varieties depicting an opportunity to improve these traits for high yielding Tossa Jute varietal development. For fibre yield content, all breeding lines of Tossa Jute were superior to one control variety (JRO-524); whereas the line $\left(\mathrm{G}_{2}=0-0412-9-4\right)$ was superior to both control varieties (BJRI Tossa pat8 and JRO-524). This line was found in cluster II with higher mean values for all studied morphological traits and higher inter-cluster distance than the other clusters. These results confirm that genetic makeup significantly contributes to variability in Tossa Jute genotypes. This study indicated the presence of high levels of genetic diversity among the breeding lines for evaluated characters. The advanced breeding line would be considered as superior one undoubtedly, and may be used to develop high yielding Tossa Jute variety following jute plant breeding systems.

\section{Acknowledgements}

All the authors acknowledge the Breeding Division, Bangladesh Jute Research Institute, Manik Mia Avenue, Dhaka for providing seed materials field and laboratory facilities financial supports etc. They also thank all the researchers and technical staff of the Breeding Division and Regional Stations of BJRI for their direct assistances in the field trial(s) management and data collection.

\section{Authors' contributions}

All the authors jointly conceptualized the experimental strategy and financial support. They supported in field data collection, laboratory works, compilation, analyses, manuscript writing, submission, correction etc.

\section{Conflict of interests}

Authors do not have any conflict of interests to declare.

\section{References}

1. Zhang L, Ibrahim AK, Niyitanga S, Zhang L, Qi J. Jute (Corchorus spp.) Breeding. Advances in Plant Breeding Strategies: Industrial and Food Crops, Springer, Cham. 2019;6:85-113. https://doi.org/10.1007/978-3-030-23265-8_4

2. Maity S, Chowdhury S, Datta AK. Jute Biology, Diversity, Cultivation, Pest Control, Fiber Production and Genetics. In: Lichtfouse E (editor). Organic Fertilisation, Soil Quality and Human Health. Sustainable Agriculture Reviews 2012;9. https://doi.org/10.1007/978-94-007-4113-3_9

3. Kar CS, Kundu A, Sarkar D, Sinha MK, Mahapatra BS. Genetic diversity in jute (Corchorus spp) and its utilization: a review. Indian Journal of Agricultural Sciences. 2009;79(8):575-86 http://epubs.icar.org.in/ejournal/index.php/IJAgS/article/view/2454 
4. Patel GI, Datta RM. Interspecific hybridization between Corchorus olitorius $\mathrm{L}$. and $C$. capsularis $\mathrm{L}$. and the cytogenetical basis of incompatibility between them Euphytica. 1960;9:89-110. https://doi.org/10.1007/ BF00023259

5. Vellend M, MA Gebe. Connections between species diversity and genetic diversity. Ecology Letters. 2005;8:767-81. https://doi.org/10.1111/j.1461-0248.2005.00775.x

6. Bhandari HR, Bhanu AN, Srivastava K, Singh MN, Shreya, Hemantaranjan A. Assessment of genetic diversity in crop plants: an overview. Adv Plants Agric Res. 2017;7(3):279-86. https://doi.org/10.15406/apar.2017.07.00255

7. Mazid MS, Rafii MY, Hanafi MM, Rahim HA, Shabanimofrad M, Latif MA. Agro-morphological characterization and assessment of variability, heritability, genetic advance and divergence in bacterial blight resistant rice genotypes. South African Journal of Botany. 2013;86:15-22. https://doi.org/10.1016/j.sajb.2013.01.004

8. Al-Jibouri HA, Miller PA, Robinson HA. Genotypic and environment variances and covariance in an upland cotton cross of inter specific origin. Agronomy Journal. 1958;50:633-36. https://doi.org/10.2134/agronj1958.00021962005000100020x

9. Swamy AA, Reddy GLK. Genetic divergence and heterosis studies of Mungbean (Vigna radiata (L.) Wilczek). Legume Research. 2004;21:115-18. https://arccjournals.com/journal/legume-research-aninternational journal/ARCC3799

10. Naik SM, Madhusudan K, Motagi BN, Nadaf HL. Diversity in soybean (Glycine max L.) accessions based on morphological characterization and seed longevity characteristics. Progressive Research - An International Journal. 2016;11(3) 377-81. https://hdl.handle.net/20.500.11766/6796

11. Bhakuni V, Shukla PS, Singh K, Singh VK. Morphological characterization and assessment of genetic variability in soybean varieties. International Journal of Current Microbiology and Applied Sciences. 2017; 6(3): 361-69. https://doi.org/10.20546/ ijcmas.2017.603.281

12. Islam MR, Islam MM, Akter N, Ghosh RK, Rafique ZA Hossain AKMS. Genetic variability and performance of Tossa Jute (Corchorus olitorius L.). Pakistan Journal of Biological Sciences.

https://doi.org/10.3923/pjbs.2002.744.745

2002:5:744-45

13. Shadakhari TV, Kalaimagal T, Senthil N, Boranayaka MB, Kambe GR, Rajesh GA. Genetic diversity studies in soybean [Glycine max (L.) Merrill] based on morphological characters. Asian Journal of BioScience. 2011;6(1):7-11. http://www.researchjournal.co.in/online/AJBS/AJBS\%206(1)/6_ A-7-11.pdf

14. Surek H, Beser N. Selection for grain yield and yield components in early generations for temperate rice. Philippine Journal of Crop Science. 2003;28(3):3-15. https://www.researchgate.net/publication/268267106

15. Larik AS, Rajput LS. Estimation of selection indices in Brassica juncea L. and Brassica napus L. Pakistan Journal of Botany. 2000;32(2):323-30.

http://www.pakbs.org/pjbot/PDFs/32(2)/16.pdf

16. Kumar P, Shukla RS. Genetic analysis for yield and its attributed traits in bread wheat under various situations. Jawaharlal Nehru Krishi Vishwa Vidyalaya Research Journal. 2002;36:95-97.

17. Islam MS, Uddin MN, Haque MM, Islam MN. Path coefficient analysis for some fibre yield related traits in white jute (Corchorus capsularis L.). Pakistan Journal of Biological Sciences. 2001; 4:47-49. https://doi.org/10.3923/pjbs.2001.47.49

18. Maji AT, Shaibu AA. Application of principal component analysis for rice germplasm characterization and evaluation. J. $\begin{array}{llll}\text { Plant } & \text { Breed. Crop } & \text { Sci. } & \end{array}$ https://doi.org/10.5897/JPBCS11.093

19. Adams MW. An estimation of homogeneity in crop plants with special reference to genetic vulnerability in the dry bean (Phaseolus vulgaris L.), Euphytica. 1977;26:665-79. https://doi.org/10.1007/BF00021692

20. Hotelling H. Analysis of a complex of statistical variables into principal components. Journal of Educational Psychology. 1933;24(7):498-520. https://doi.org/ 10.1037/h0070888
21. Amy EL, Pritts MP. Application of principal component analysis to horticultural research. Hort Sci. 1991;26(4):334-38. https://doi.org/10.21273/HORTSCI.26.4.334

22. Clifford HT, Stephenson W. An Introduction to Numerical Classification. Academic Press, London 1975;229. https://catalogue.nla.gov.au/Record/302559

23. Guei RG, Abamul FJ, Karim T, Naman S. Genetic variability in morphological and physiological traits within and among rice species and their interspecific progenies. Agronomieafricaine. 2004; 16(1): 15-32. https://www.ajol.info/index.php/aga/article/ download/1636/534

24. SRDI-Soil Resource Development Institute, Ministry of Agriculture, 2017. Annual Report of SRDI (2017-2018), Dhaka, Bangladesh.

25. Gomez KA, Gomez AA. Statistical procedures for agricultural research $2^{\text {nd }}$ ed. An International Rice Research Institute Book, A Wiley-inter-science Publication, JOHN WILEY \& SONS, 1984 https://pdf.usaid.gov/pdf_docs/PNAAR208.pdf

26. Girma T, Tilahun Y, Demisue M. Design and Analysis of field experiments. In: Agriculture. Technical Manual No. 15 Ethiopian Agricultural Research Organization. Addis Abeba Ethiopia,

2002 http://publication.eiar.gov.et:8080/xmlui/bitstream/handle/123456 789/3144/28\%20pdf1ab\%20bbbyyy.pdf?sequence=1\&isAllowed=y

27. BARJ-Basic and Applied Research on Jute Project, Bangladesh Jute Research Institute. Leaflet prepared on latest released variety of BJRI. Dhaka, Bangladesh, 2018.

28. Islam MM, Ali MS. Agronomic research advances in jute crops of Bangladesh. AASCIT Journal of Biology 2017;3(6):34-46. http:// www.aascit.org/journal/archive?journalId=980\&issueId=9800306

29. STATISTIX- Statistical analysis programme (29 August, 2017) https://statistix. informer.com/10.0.0.9/

30. Johnson HW, Robinson HF, Comstock RW. Estimates of genetic and environment variability in Soybean. Agronomy Journal. 1955;47:314-318.

http://dx.doi.org/10.2134/agronj1955.00021962004700070009x

31. Cohen J. Statistical Power Analysis for the Behavioral Sciences, 2nd ed. Hillsdale, NJ: Erlbaum, 1988 http://www.utstat.toronto.edu/ brunner/oldclass/378f16/ readings/Cohen Power.pdf

32. Burton GW. Quantitative inheritance in grasses. 6th Intl Grassland Cong Proc. 1952;1:227-38.

33. Lush JL. Heritability of quantitative characters in farm animals. Hereditas. 1949;35(S1):356-75. https://doi.org/10.1111/j.1601-5223.1949.tb03347.x

34. Hanson $\mathrm{CH}$, Robinson HF, Comstock RE. Biometrical studies of yield in segregating populations of Korean Lespedza or Korean clover (Kummerowia stipulacea). Agron J. 1956;48:268-72. https://doi.org/10.2134/agronj1956.00021962004800060008x

35. Burton GW, Devane EH. Estimating heritability in tall fesscusce from replicated clone natural materials. Journal of Agronomy. 1953;45:171-81.

https://doi.org/10.2134/agronj1953.00021962004500100005x

36. Comstock RE, Robinson HF. Genetic parameters, their estimation and significance. Proc. $6^{\text {th }}$ Intercropping, Grassland Cong. 1952;1:284-91.

37. Karim D, Sarkar U, Siddique MNA, Miah MAK, Hasnat MZ. Variability and Genetic parameter analysis in aromatic rice. Int J Sustain Crop Prod. 2007;2(5):15-18.

38. Karim D, Siddique MNA, Sarkar U, Hasnat MZ, Sultana J. Phenotypic and genotypic correlation co-efficient of quantitative characters and character association of aromatic rice. Journal of Bioscience and Agriculture Research, 2014 01(01):36-48. https://doi.org/10.18801/jbar.010114.05

39. Jolliffe IT. Principal Component Analysis. New York: Springer, 2002. https://www.springer.com/gp/book/9780387954424

40. Jolliffe IT, Cadima J. Principal component analysis: a review and recent developments. Phil Trans R Soc. 2016;A 374:20150202. http://dx.doi.org/10.1098/rsta.2015.0202

41. Spuhler JN. Advanced statistical methods in biometric research. By C. Radhakrishna Rao. John Wiley \& Sons, Inc., 
New York, N. Y. 1952. 390 pp. American Journal of Physical Anthropology 1954;12(2):268-70. https://doi.org/10.1002/ajpa.1330120224

42. Singh RK, Choudhary BD. Biometrical methods in quantitative genetic analysis. ISBN 13: 9788176633079, Kalyani Publishers, New Delhi, India. 1979:211-15. https://www.sapnaonline.com/books/biometrical-methods-inquantitative-genetic-analysis-4829916

43. Malek MA, Rafii MY, Afroz MSS, Nath UK, Mondal MMA. Morphological characterization and assessment of genetic variability, character association and divergence in soybean mutants. The Scientific World Journal, Hindawi Publishing Corporation. 2014;AID968796:12 http://dx.doi.org/10.1155/2014/968796

44. Jatothu JL, Kumar AA, Choudhary SB, Sharma HK, Maruthi RT, Kar CS, Mitra J. Genetic diversity analysis in Tossa jute (Corchorus olitorius L.) germplasm lines. Journal of Applied and Natural Science. 2018;10(1):1-3. https://doi.org/10.31018/jans.v10i1.1566

45. XLSTAT-Statistical Software for Excel: Statistical and data analysis solution (Version 2020.4). New York, USA, 2020 https://www.xlstat.com

46. Islam MS, Nasrin A, Begum S, Haque S. Correlated response and path analysis in Tossa jute (Corchorus olitorius L.) Bangladesh Journal of Botany. 2004;33(2):99-102. http://www.scopus.com/inward/record.url?eid=2s2.033750342488\&partnerID= MN8TOARS

47. Mohammed A, Geremew B, Amsalu A. Variation and associations of quality parameters in Ethiopian Durum wheat (Triticum turgidum L. var. durum) genotypes. International Journal of Plant Breeding and Genetics. 2012;6(1):17-31. http://dx.doi.org/10.3923/ijpbg.2012.17.31

48. Segherloo AE, Mohammadi SA, Sadeghzadeh B, Kamrani M. Study of Heritability and Genetic Advance of Agronomic Traits in Barley (Hordeum vulgare L.) and Graphic Analysis of Trait Relations by Biplot. Jordan Journal of Agricultural Sciences, 2016; 12(1): 299-310. https://journals.ju.edu.jo/JJAS/article/download/7992/5125
49. Kumar AA, Choudhary SB, Sharma HK, Maruthi RT, Jatothu JL Mitra J, Karmakar PG. An International Quarterly Journal of Life Sciences: The BioScan. 2018;13(2),SL-39:703-06 https://thebioscan.com/journal.php?edition= TnVtYmVyIDI=\&volume $=$ Vm9sdW1l IDEz

50. Anand SC, Torrie JH. Heritability of yield and other traits and interrelationship among traits in the $\mathrm{F}_{3}$ and $\mathrm{F}_{4}$ generations of three soybean crosses. Crop Science. 1963;3:508-11. https://doi.org/10.2135/cropsci1963. 0011183X000300060015x

51. Weber CR, Moorthy BR. Heritable and non-heritable relationships and variability of oil content and agronomic characters in the F2 generation of soybean crosses. Agronomy Journal. 1952;44:202-09. https://doi.org/10.2134/agronj1952.00021962004400040010x

52. Roy SK, Das B, Kale VA, Haque S. Genetic divergence study for yield and quality traits in Tossa jute (Corchorus olitorius) Journal of Crop and Weed. 2011;7(1):130-32. http://www.cropandweed.com/archives/2011/vol7issue1/32 .pd

53. Ghosh RK, Wongkaew A, Sreewongchai T, Nakasathien S, Phumichai C. Assessment of genetic diversity and population structure in jute (Corchorus spp.) Using Simple Sequence Repeat (SSR) and Amplified Fragment Length Polymorphism (AFLP) Markers. Kasetsart J (Nat. Sci.). 2014;48:83-94. https://pdfs.semanticscholar.org/d281/ 402621a46abd31270c16c3deee6c72fc7f10.pdf

54. Akter N, Islam MM, Yahiya ASM, Newaz MA. Genetic divergence for fibre and seed characters in Tossa jute (Corchorus olitorius L.). Journal of Experimental Bioscience, 2010;(1):7-12.

http://www.bioscience-associates.com/2013/02/geneticdivergence-for-fibre-and-seed.html

55. Denton OA, Nwangburuka CC. Morphological diversity among Corchorus olitorius based on single linkage cluster analysis and principal component analysis. Jordan J Biol Sci 2012; 5:191-96. http://jjbs.hu.edu.jo/ files/v5n3/Paper_Number_7.pdf 